\title{
Building Independent Villages through Collaborative Governance by Village-Owned \\ Enterprises \\ (Best Practice from Panggungharjo Village, Central Java, Indonesia)
}

\author{
By \\ Sri Juni Woro Astuti ${ }^{*)}$ and Falih Suaedi ${ }^{*}$
}

\begin{abstract}
This study aims to develop a collaborative governance model applied by village-owned enterprises called "BUMDes" which has become one of the keys to the success of the village government in improving the economy and welfare of rural communities becoming an independent village. The research method used is descriptive qualitative method with a case study approach that is by taking the setting and research focus on the success of BUMDes in the village of Panggungharjo, Bantul Regency, Central Java Province. Primary data collection was carried out through in-depth interviews with several key informants and supporting informants, which were determined by snowball sampling. The main informants consisted of: the village head, the head of the village deliberation body, and the village secretary who then rolled out to several supporting informants consisting of the BUMDes officials, community leaders, and the private sector who collaborated with the Panggungharjo BUMDes. In addition, secondary data needed is obtained through documentary studies. This research will produce a collaborative governance model that is expected to be used as a reference for the management of other BUMDes in Indonesia.
\end{abstract}

Keywords: village-owned enterprises, collaborative governance, community welfare.

\section{Introduction}

since the Village Fund Allocation Program was implemented in early 2015, villages in Indonesia are increasingly eager to establish Village Owned Enterprises or called BUMDes. BUMDes are managed by the village government and the village community to strengthen the local economy. BUMDes built based on the village needs and potency. BUMDES is a pillar of economic activity in the village that functions as a social institution and at the same time as a commercial institution that aims to, expand market access, create a conducive business climate, improve the economy, provide post-harvest infrastructure and provide capital assistance.

The development of BUMDes can be done by developing services, village financial institutions, and trading and service business units. Examples of BUMDes business units are banking financial services such as transfers, repayment of mortgage loans, distribution of People's Business loans, cooperatives, agriculture, shops, payment services, fertilizer distributors and subsidized seeds and other business units based from community needs.

The development of BUMDes as an innovation in the village received very enthusiastic support as evidenced by its rapid development from 2015 from 1,022 units to 39,000 units from 74,910 villages in 2018 (www.berdesa.com, 28 July 2018). However, there are still many BUMDes that have not run effectively because the managers have not really focused on running the BUMDes. On the other hand, several BUMDes have managed to reap significant benefits even up to billions of rupiah. 
BUMDES Panggung Lestari is one of the successful BUMDes that is located in the village of Panggungharjo, Bantul District, Central Java. The success of BUMDes is different from other BUMDes, where they have collaborated with various parties in various programs since 2013. Several programs initiated by BUMDes Panggung Lestari that are able to work together with the private sector and the community include waste treatment programs, nyamplung oil production and processing used cooking oil to be used as new energy. To produce oil, the BUMDes collaborates with the private sector and village cooperatives. Whereas in the processing of used cooking oil, Bumdes cooperates with the private sector as producers and the community as suppliers of used oil.

In this context the Panggungharjo village government has implemented collaborative village governance, through the establishment of village-owned enterprises which then collaborate with the private sector and also the community in an effort to improve community welfare. Collaborative governance recently has become a strategy choice to accelerate the development process both at the level of the central government and regional governments. However, this has not been widely applied at the level of village government.

As a new approach in the implementation of village governance, the implementation of collaborative governance certainly requires specific processes and approaches depending on the readiness, capabilities and characteristics of the village apparatus and the village community. This paper, therefore, aims to develop a model for implementing collaborative governance in rural development through the operationalization of village-owned enterprises by taking case studies in the village of Panggungharjo, Bantul district, Central Java Province, Indonesia.

\section{Theoretical Review}

In line with the era of democracy which followed by the increasing demand of openness in governance, stakeholder involvement is a necessity. In addition, the capacity of government resources become more limited in financial resources, human resources, technology and management capacity that encourage the emergence of new approaches in government practice. The new approach began with the emergence of a governance paradigm where government and development affairs were no longer a government monopoly, but involved various actors in the public policy process (Marc, 2011). Since then various models have developed based on governance principles.

Starting from the principles of governance, the concept of Collaborative Governance developed where the government, society, and the private sector communicate with each other and work together to achieve common goals and to benefit each other. Ansell and Gash (2008) describe collaborative governance as a governance arrangement where one or more public institutions directly involve non-government stakeholders in a collective decisionmaking process that is formal, consensus-oriented, deliberative which aims to create and implement public policies and manage program or public assets (Ansell and Gash, 2008: 543571); Afful-Koomson and Kwabena, 2013: 13).

The collaborative governance model according to Ansell and Gash (2007: 550-561) consists of four main variables, namely initial conditions, institutional design, leadership and collaborative processes. The initial conditions observed consist of three broad variables: an 
imbalance between the resources or strengths of different stakeholders, incentives that must be collaborated by stakeholders, and a history of conflict or cooperation among stakeholders. Leadership is widely seen as an important element in bringing parties to the table and to direct them through rough patches of collaborative processes. Institutional design refers here to basic protocols and basic rules for collaboration, which are very important for procedural legitimacy of collaborative processes. The collaborative governance process models sometimes describe collaboration as developing gradually. According to Ansell and Gash (2007) the collaboration process is not described as a linear stage but as a cycle process which includes: face to face dialogue, trust builbing, intermediate outcomes.

Emerson, Kirk, Nabatchi, Balogh (2012: 1-29) define collaborative governance broadly as a process and structure of decision making or public policy and management that involves people constructively between public institutions, levels of government, both in the public, private and civilians to carry out common goals that cannot be solved individually. In general, in the implementation of collaborative governance involves common norms and mutually beneficial interactions between governance actors so that the positive objectives of each party can be achieved.

Wildavsky (1973) as quoted by Wanna (2008), in interpreting collaboration and coordination involving several different dimensions. First, collaboration can involve collaboration to build similarities, increase consistency and align activities between actors. Second, collaboration can be a negotiation process, which involves readiness to compromise and make trade-offs. Third, collaboration can involve the role of supervision, checking, pulling together and coordinating the center. Fourth, collaboration can involve, power and coercion, the ability to impose results or impose their own preferences on others, to a certain extent, by their compliance or involvement. Fifth, collaboration can involve future commitments and intentions, prospective behavior, planning or preparation to align activities. Finally, collaboration can involve engagement, development of internal motivation and commitment to personal projects, decisions, organizational goals or strategic goals (Wanna, John in O'Flynn, Janine and John Wanna, 2008).

In addition to the various dimensions as stated by Wildavsky above, in general this governance model is characterized by equality among stakeholders, participatory nature and avoiding political and administrative pressure (consensus), despite the formal structure, it remains flexible and tends to be simple, and focuses on resolving policies and programs more effectively. This model is very relevant to encourage the effectiveness of community empowerment programs or programs to improve community welfare where the government is no longer the sole subject that determines the success of development programs but is more determined by the participation and consensus of the stakeholders. However, we need to anticipate some challenges that can become obstacles in the implementation of collaborative governance such as that collaborative arrangements are expensive in time and resources, inherently fragile, need to be continuously managed and maintained, involving trust and different reciprocity and unique obligations ( Huxham 2005; Entwistle and Martin 2005; Agranoff 2006; Bardach 1998; Wanna 2008).

The implementation of the concept of collaborative governance can be assessed from the degree of collaboration, which includes the extent to which collaborative and consensus commitments are needed between actors (parties) and the extent of collaboration that has 
implications for political and managerial risks. In table 1.1. the degree of collaboration according to Wanna (2008) explained.

Table 1.1 The scale of collaboration

\begin{tabular}{|l|l|l|}
\hline No & Degree of collaboration & What is involved-activities \\
\hline 1 & $\begin{array}{l}\text { Highest level: high normative } \\
\text { commitment to collaboration; often } \\
\text { highest political/managerial risks }\end{array}$ & $\begin{array}{l}\text { Transformative interaction between network } \\
\text { actors; substantive engagement and } \\
\text { empowerment; search for high degree of } \\
\text { stakeholder and inter-actor consensus and } \\
\text { cooperation; coalition building by } \\
\text { government and non-government actors }\end{array}$ \\
\hline 2 & $\begin{array}{l}\text { Medium-high level: strong normative } \\
\text { orientation; high level of } \\
\text { political/managerial risk }\end{array}$ & $\begin{array}{l}\text { Strong engagement of stakeholders in } \\
\text { decisions or policy process and } \\
\text { implementation; devolving decision-making } \\
\text { capacities to clients; more complex } \\
\text { innovations in policy-delivery processes }\end{array}$ \\
\hline 3 & $\begin{array}{l}\text { Medium level: commitment to } \\
\text { multiparty input and buy-in; moderate } \\
\text { levels of political/managerial risk }\end{array}$ & $\begin{array}{l}\text { Formal commitment to inter-agency } \\
\text { consultation and collaboration; joined } \\
\text { government strategies; formal joint } \\
\text { involvement exercises and joint funding } \\
\text { Initiatives }\end{array}$ \\
\hline 4 & $\begin{array}{l}\text { Medium-low level: operational forms } \\
\text { of collaboration to 'get job done'; some } \\
\text { political/managerial risk }\end{array}$ & $\begin{array}{l}\text { Forms of co-production; technical } \\
\text { improvements in delivery chains; assistance } \\
\text { to comply with obligations; direct } \\
\text { consultation with clients over delivery and } \\
\text { compliance systems; systematic use of } \\
\text { evaluation data; public reporting on targets } \\
\text { informed by client preferences }\end{array}$ \\
\hline 5 & $\begin{array}{l}\text { Lowest level: marginal operational } \\
\text { adjustments, low levels of } \\
\text { political/managerial risk }\end{array}$ & $\begin{array}{l}\text { Incremental adjustments using consultative } \\
\text { processes; client discussions and feedback } \\
\text { mechanisms; gaining information on } \\
\text { needs/expectations of others }\end{array}$ \\
\hline
\end{tabular}

Source: Wanna, John in O'Flynn, Janine and John Wanna, 2008.

Collaboration does not occur in a vacuum. Therefore, studying collaboration is also needed understanding about the context and purpose of collaboration. There are eight dimensions of context and purpose of collaboration (John Wanna, 2008), namely: 1) dimensions of power,

2) level of commitment, 3) internalization of culture, 4) dimensions of strategic, 5) dimensions of processes and results, 6) dimensions of goals, 7) visibility and awareness dimensions, and 8) problems encountered. Where in each of these dimensions there are alternative choices and motivations underlying them. Each of these choices and motivations will certainly have a different impact on the application of collaboration. Various dimensions of context and objectives along with alternative possibilities or choices for the creation of a collaboration are described in Table 1.2 below. 
Tabel 1.2. Context, Purpose, Choices or Motivational Possibilities

\begin{tabular}{|c|c|c|}
\hline Context \& purpose & \multicolumn{2}{|c|}{ Choices or motivational possibilities } \\
\hline Power dimension & \begin{tabular}{|ll} 
Coercive & And \\
Collaboration & \\
\end{tabular} & $\begin{array}{l}\text { Persuasive and voluntary } \\
\text { involvement in collaboration }\end{array}$ \\
\hline Com & \begin{tabular}{|l|} 
Meaningful and substantive \\
Collaboration
\end{tabular} & $\begin{array}{l}\text { Meaningless and cosmetic } \\
\text { collaboration }\end{array}$ \\
\hline $\begin{array}{l}\text { Cult } \\
\text { inter }\end{array}$ & $\begin{array}{l}\text { Philosophical commitment } \\
\text { collaboration-development } \\
\text { collaborative cultures }\end{array}$ & $\begin{array}{l}\text { Collaboration as a tool, an } \\
\text { available instrument-no real } \\
\text { commitment to collaboration as a } \\
\text { modus operandi }\end{array}$ \\
\hline Stra & $\begin{array}{l}\text { tion for positive and } \\
\text { reasons }\end{array}$ & $\begin{array}{l}\text { ration for negative and/or } \\
\text { ive strategies }\end{array}$ \\
\hline $\begin{array}{l}\text { Meal } \\
\text { dime }\end{array}$ & $\begin{array}{l}\text { oration as a means and } \\
\text { s; stages, due process }\end{array}$ & $\begin{array}{l}\text { Collaboration as an end and } \\
\text { outcome; shared results, outcome } \\
\text { orientation }\end{array}$ \\
\hline Goal & 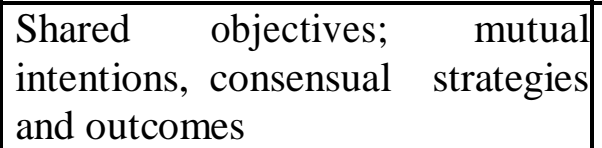 & $\begin{array}{l}\text { Competing objectives; different } \\
\text { reasons for participating in } \\
\text { collaboration }\end{array}$ \\
\hline $\begin{array}{l}\text { Visibility and } \\
\text { awareness dimension }\end{array}$ & $\begin{array}{l}\text { Overt and public forms of } \\
\text { collaboration; awareness of } \\
\text { collaboration is high }\end{array}$ & $\begin{array}{l}\text { Covert and behind-the-scenes } \\
\text { collaboration; unawareness of } \\
\text { collaboration }\end{array}$ \\
\hline Problem applicability & \begin{tabular}{|l|} 
Collaboration on simple \\
problems; simple objectives and \\
Responsibilities
\end{tabular} & $\begin{array}{l}\text { Collaboration on 'wicked' } \\
\text { problems; defying description and } \\
\text { solutions }\end{array}$ \\
\hline
\end{tabular}

Source: Wanna, John in O’Flynn, Janine and John Wanna, 2008.

To understand the choices and motivations that underlie the context and purpose of collaboration, collaborative governance studies also need to know what factors are driving them. There are 3 (three) factors that can be the driving force of collaborative governance, namely: external drivers, internal drivers, willingness factors in relation to the roles and responsibilities of government (Emerson, Nabatchi, Balogh, 2012: 1-29). External drivers include greater pressure from globalization, connectivity and international travel, knowledge of other cultures, information technology (IT) and technological sophistication. Internal movers within the government include political demands for public officials to be 'responsive' to the needs of the community. Whereas willingness factors include political strategies for common goals and understanding of problems throughout society - building consensus among players and coalitions of support for certain actions.

Kirk Emerson, Nabatchi, and Balogh (2012) in his article called the government that collaborates as a collaborative governance regime (CGR) in which there are three driving components of the dynamics of collaboration, namely principled engagement, shared motivation, capacity for joint action. The three components of collaborative dynamics work in interactive and iterative way to produce collaborative actions or the steps taken in order to implement the shared purpose of the CGR.

\section{Research methods}

Based on the theoretical review above, then in this study a model or pattern of collaborative governance will be formulated in the development of Mandiri Villages especially with the 
existence of Village Owned Enterprises (BUMDES). This study took the location setting in the village of Panggungharjo as one of the villages that managed BUMDES by applying the collaborative concept. Therefore this research can be categorized as case study research with best practice patterns. Stake (2005) states that case study research aims to reveal the peculiarities or uniqueness of the characteristics contained in the case under study. Case studies aim to give the reader a sense of "being there" by providing a highly detailed, contextualized analysis of an "an instance in action". The researcher carefully delineates the "instance," defining it in general terms and teasing out its particularities (VanWynsberghe dan Khan, 2007, 4). According to Lincoln and Guba (1985), case study research is a research that seeks to reveal a variety of valuable learning (best learning practices) obtained from an understanding of the case under study.

The purpose of this research is to develop a model of rural development through collaborative governance between BUMDES, the private sector, and the community. To limit the scope of the study, this study focused on the context and purpose of collaboration, the degree of collaboration, and the driving factors of collaboration. The approach used is a qualitative approach with the aim that more can provide in-depth explanation of how the efforts of the village government which in this case are represented by BUMDES so that they are successful in carrying out collaborative management that is mutually beneficial between the parties that collaborate. Data collection is done by in-depth interview and documentary techniques. The interviews were conducted on several key informants (key), namely the village head, BUMDES management, the private sector in this case PT. Mertani Innovation Group and PT.Danone Aqua and representatives of the community. Furthermore, data processing uses is interactive methods. The research framework can be described as follows:

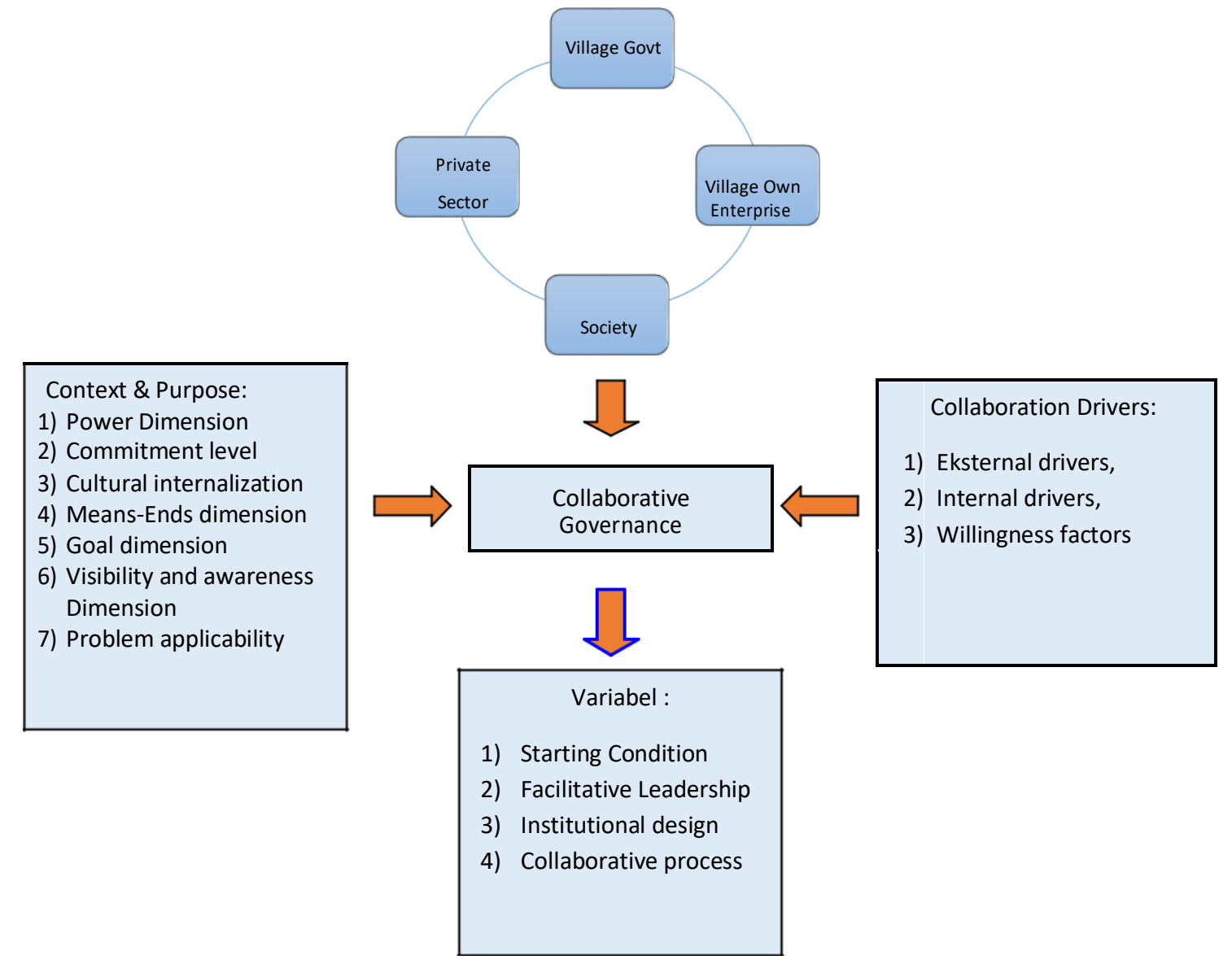

Figure 1. Research Framework 


\section{Findings}

Panggungharjo is an example of another success story from good village governance. Located in Sewon Subdistrict, Bantul Regency, Panggungharjo Village administratively consists of 14 hamlets divided into 118 RTs that inhabit an area of 564.5 hectares and a population of 25,727 people. In March 2013, the Panggungharjo Village Government established BUMDes which was named BUMDes Panggung Lestari as an effort to utilize village potential and is expected to be an entity capable of leveraging the economy of the community. The establishment of BUMDes on Sustainable Stage comes from the activities of the KUPAS or the waste management business group that was endorsed through Regulation No. 7 of 2013 concerning the Establishment of Village Owned Enterprises (BUMDes).

Since the last four years the village government has had a real action by managing a Waste Management House (RPS). Waste management in Panggungharjo Village is based on two perspectives, namely the environmental health perspective as well as the business (business) perspective therefore waste management is carried out by Village Owned Enterprises (BUMDES). Waste management has a variety of potential that if managed optimally can produce economic and environmental benefits. BUMDES Stagelestari has several productive activities carried out collaboratively with several parties, namely:

\section{Garbage processing business group abbreviated: KUPAS "}

The KUPAS unit was established in early 2013 which originated from a concern about the declining level of environmental cleanliness caused by the increasing volume of waste produced by the community, thus requiring serious handling. Initially in waste management, KUPAS did not prioritize profit. But as a social service to help cleanliness in the community, in its development KUPAS becomes part of the business unit of BUMDes Panggung Lestari. Institutional reorientation becomes profit oriented activities by diversifying business. The management is carried out professionally in order to develop and be effective to increase Village Original Income.

The choice of this waste management business is in addition to optimizing any local potential that is owned by the village, as well as in order to conduct policy interventions in encouraging the establishment of a new culture of sustainable environmental management. As of the end of 2017, capitalization of managed capital reached Rp 344,363,500, - or increased by more than $9 \mathrm{x}$ from the initial investment capital deposited by the village in the amount of Rp 37,000,000, - (BUMDES Panggung lestari, 2018). Some of the benefits resulting from KUPAS activities are: 1) Managing household waste in the village so as to create a healthy rural living environment; 2)The absorption of more labor in the village from the development of this activity; 3) To provide innovative and productive household waste management systems for other villages in Indonesia.

In this waste management, the village government collaborates with community groups that are accommodated in the PKK or Family Welfare Development Organization. Next with PT. Danone Aqua for processing used cooking oil with a minimum capacity of 5 tons

/ month. The waste is managed starting from being sorted, recycled, and sold. Organic waste is converted into fertilizer, non-organic waste is converted into craft materials, while residual waste is discarded. For its success, in 2015, this village won 1st rank in the National Village Competition. Previously, in 2014, Panggungharjo Village was crowned a 
model village by the Corruption Eradication Commission (KPK) as a clean and corruption-free village government by making a short film titled "Merah Putih on Panggungharjo". This success is certainly due to the synergy between the Panggungharjo Village Government, the PKK organization, the support of the villagers, the Sewon District Government, the Bantul Regency Government and the Yogyakarta Special Region Government.

\section{Refine Used Cooking Oil (R-UCO)}

BUMDes Panggung Lestari with PT. Tirta Investama Klaten (Danone Aqua) collaborates to develop Refined Used Cooking Oil (R-UCO) as an alternative fuel for solar substitutes for industrial machinery at the Panggungharjo Village Hall. The goal of producing used cooking oil in Panggungharjo Village is to reduce waste that pollutes the environment. The production of used cooking oil can also be a livelihood for Panggungharjo Village residents. Parties involved in the production of R-UCO in addition to Bumdes and PT Danone Aqua, also involved the participation of community members and used cooking oil collectors as suppliers. Processing of used cooking oil with a minimum capacity of 5 tons / month.

Nyamplung oil.

The processing and production of nyamplung oil is carried out collaboratively with PT. Martani Innovation Group which acts as a consultant. While the party who produced it initially was Cooperative "Dewi Kunti" managed by PKK group who is currently preparing for the establishment of a company called "PT. Synergy Panggung Lestari". The role of the village government and BUMDes are as initiator and facilitator. For the supply of raw materials, it is currently partnering with hundreds of farmers along the southern coast of Java which are included in the districts of Purworejo, Kebumen and Cilacap, Central Java.

\section{Mataraman Village}

Village-owned enterprises (BUMDes) in Panggungharjo village continue to issue innovative ideas to revive and develop economic productive activities by utilizing village land for an area of approximately 6 hectares by taking place in Pelemsewu Hamlet, Desa Panggungharjo. Mataraman village emphasized the past civilization with the style of the Mataram kingdom by displaying 19th-century clothing, food and board aspects in the complex.

"We have built Mataraman Village, there is an educational value in it, it is an effective medium to provide learning for all of us, we are now invited to look at this common ancestor who has a culture that is identical with the Mataram kingdom. Therefore we try to show that culture through Mataraman Village, "said the Head of the Village of Panggungharjo, Wahyudi Anggoro (August, 2018).

Kampoeng Mataraman as one of the business units of BUMDes owned by Panggungharjo Village was officially opened since June 2017. The benefits of Kampoeng Mataraman reached Rp. 3 billion, this is a very good achievement in its management. Mataraman village also proves, with modern management, the businesses built by BUMDes can suck up a lot of labor and various village agricultural commodities supplied to meet the needs 
of restaurant consumers ranging from rice, vegetables to fruits. Mataraman village, revives many economic aspects for the village.

From the four productive businesses initiated by the village government through the VillageOwned Enterprises (BUMDes) in Panggungharjo Village, two of them were carried out through collaborative governance by involving the private sector, namely R-UCO and nyamplung oil. While the business of KUPAS and Kampung Mataraman is purely managed by elements from the village itself, they are Village Government, BUMDES, PKK and the community.

The discussion then focused on the implementation of collaborative governance models by examining several dimensions of context and Puspose of Collaborative governance as follows:

\section{Context and Purpose of Collaborative governance \\ Power Dimension}

Based on the results of interviews with several informants in the village of Panggungharjo, it can be concluded that the leadership of the village head is one of the determining factors for the successful implementation of collaborative governance. The leadership style adopted by Wahyudi Anggoro is a transformational style, because since the beginning of his leadership many made changes towards a better direction. Changes that have been made and successfully implemented effectively include : 1) developing village information systems based on village (web) portals, village newspapers and village archive systems that are managed based on archival standards by archivist functional positions, 2) to improve apparatus discipline and performance, since 2015 he has been system engineering by implementing merit systems and conducting Job Analysis, Workload Analysis (ABK) to reward those who perform.

The idea of collaborating with the private sector to produce nyamplung oil and processing cooking oil waste was initiated by the village head without forced use. The idea of the village head was conveyed to the village officials, managers of BUMDes and community groups and received a positive response.

\section{Commitment level}

The development of the Panggungharjo village since the existence of BUMDes has progressed very rapidly. According to the informant from the BUMDes management element stated that the high commitment of all BUMDes managers and staf was the second success factor after leadership. According to him, leadership alone without being supported by the commitment of all parties involved, the ideas made by the village head cannot necessarily be realized properly as it is today.

It can be said that the degree of commitment shown by the collaborating parties is not only a formality but truly a substantial commitment. This was indicated by the Director of BUMDes who could translate the direction of the village head and follow up on various work programs. Significant commitment as a key to the success of collaborative governance is also demonstrated by transparency and professional management in rolling out village funds for the management of BUMDes. There is no suspicion of the existence 
of village apparatuses seeking their own profit. Because bookkeeping can be accessed by the public through BUMDes' website.

The commitment of the community is shown by high support and participation, such as in collecting garbage and sorting organic and unorganic waste in an orderly manner. So that the results of waste collection alone are able to provide large profits where the initial capital is only 37 million rupiah, now the managed assets have reached 360 million rupiah.

\section{Cultural internalization}

The context dimension and the third purpose of collaborative governance are cultural internalization. With the collaboration between the village government, BUMDes, the private sector and the community in processing waste, there has been a process of cultural transformation. This is as stated by the Director of BUMDes that the existence of BUMDes has become an agent of cultural change. The following is the statement: "The choice of this waste management business sector, in addition to optimizing any local potential that is owned by the village, also in order to carry out policies encourages the birth of a new culture of sustainable environmental management". In addition, with the existence of BUMDes, it has encouraged cultural change towards a more creative and productive society and has an entrepreneurial spirit.

\section{Means-Ends dimension}

Collaboration between the village government, BUMDes, the private sector and the community is a stage or a way to achieve a greater goal of improving the welfare of the Panggungharjo village community. As stated by the Director of BUMDes

Panggunglestari, the following: "The collaboration carried out by BUMdes actually does not necessarily seek profit but prioritizing the benefits that can be felt directly by the community is far more important. Because we are under the village administration, we are formed by the village government because the village is a service. " To be able to play a role as a realization of social change towards prosperity, according to him, BUMDes Panggung Lestari focuses its efforts on the field of environmental management services, especially household waste management.

Garbage collection efforts in Panggungharjo Village were carried out by involving PKK as garbage collection agents from each of the Family Heads. Each family is required to pay a levy of Rp. 20,000 / month. The waste management flow starts from the collection of garbage in 1,700 customer points. Garbage is sorted into 3 categories, namely organic, inorganic and residual - organic fertilizer (organic category) - scrub (non-organic) and residues distributed to TPS. Since 2014 the results obtained from the waste retribution amounted to Rp. 32 million. From sorting and selling garbage they get Rp. 10 million. Because the community producing household waste is a maximum of $4 \mathrm{~kg}$, if it is above 4 $\mathrm{kg}$ there will be additional, for example there is a boarding house - 1 room is usually $\mathrm{Rp}$. 5,000 . If there is a restaurant, a small restaurant / large restaurant. For large restaurants usually Rp. 700,000 / month The advantage of selling scraps made from inorganic waste that reaches 60-80 million rupiah / year.

BUMDes Panggung Lestari is now processing nyamplung seeds for oil and managing cooking oil waste. The processing of used cooking oil into diesel oil itself, BUMDes Panggung Lestari in collaboration with PT Tirta lnvestama (Danone AQUA) since 2014 
has been able to produce around 5 tons of used cooking oil with an income range of $\mathrm{Rp} 35$ million and the management of it into oil of 500 liters with an income of around 125 million rupiah. With a price of $\mathrm{Rp} 7,500$ / liter. "There are about 9 thousand liters of used cooking oil or used cooking oil that is disposed of every month. Therefore we try to manage it ourselves, "he said. According to Pambudi, Bumdes Panggung Lestari is open to working with anyone to increase business scale.

\section{Goal dimension}

Collaboration involving the village government, BUMDes, the community and the private sector must of course be built on mutual goals that are mutually beneficial. The village government is obliged to improve the welfare of the community through the provision of better public services. The objectives of the private sector are PT Tirta lnvestama (Danone AQUA) as part of a business entity that actively carries out initiatives to reduce the carbon footprint caused by its business operations by reducing energy use and the use of renewable energy such as solar electricity and R-UCO this. Based on interviews with the Manager Representative of PT. Mertani Group in Panggungharjo Village obtained information about the benefits obtained by PT. Mertani Group includes:

- Can improve relationships or work networks

- Become a starter in applying technology to the community

- Become a place to carry out innovative ideas

While the benefits that are indirectly obtained by the community are in the form of increased welfare with the existence of new sources of income managed by the PKK organization which will then establish a company namely PT. Synergy Panggung Lestari.

\section{Visibility and awareness dimension}

Judging from the motivation of collaboration, it is clear that the aim is to realize the innovative ideas, which can not be realized independently by the village government of Panggungharjo or by the village-owned business entity. For this reason, the BUMDes felt it was necessary to collaborate with the private sector that has relevance and competence in accordance with the purpose of collaboration. PT. Tirta Investama (Aqua Danone) because the company always strives to create an environmentally friendly company. As stated by the Director of Sustainable Development, Karyanto Wibowo, that Danone Aqua has done many initiatives that have a positive impact on the environment, one of which is the use of Refined Used Cooking Oil. The aim or benefit to be obtained is to increase the volume of UCO fuel usage at Aqua Plant in Klaten Regency. This collaboration has thus been based on a clear awareness and engagement between the two parties.

Problem applicability

Collaboration that runs in R-UCO and Nyamplung Oil processing can be said to be simple collaboration. In the sense that the problem underlying the collaboration is not a complex problem and does not require complex strategies. As explained earlier, this collaboration stems from the idea of the Panggungharjo Village Chief to encourage creative economic activities that benefit the rural community and not benefit individually. For the R-UCO business, the goal is simple, to encourage productive economic activities by utilizing 
cooking oil waste and to prevent environmental pollution which is welcomed with the aim of the private sector to obtain environmentally friendly fuels, namely UCO fuel. As for collaboration in the oil business, which is more business oriented, both parties have goals that are mutually beneficial as a simple business relationship.

So the Collaborative governance in terms of 7 dimensions of the context and objectives above can be concluded as follows:

- Power dimension: more persuasive and voluntary where the community, BUMDes managers, and PKK organizations together and without coercion are binding on each other to collaboratively succeed BUMDES programs.

- Commitment level: quite high

- Cultural internalization: collaboration that is built at the same time as a means of cultural change in the village community to become more environmentally conscious.

- Means-ends dimension: collaboration as a way to achieve a greater goal of improving the welfare of the Panggungharjo village community.

- Goal dimension: clear, mutual intentions

- Visibility and dimension awareness: ovet and public forms of collaboration

- Problem applicability: simple problems

\section{Collaboration Drivers}

Based on the results of the study it can be concluded that the driving factor of collaboration is more internal rather than external driver. Where the village government and BUMDes feel they have a great commitment and responsibility to improve community welfare. The efforts are concentrated on developing Village Owned Enterprises as a driver of productive economic activities. As a form of accountability for receiving village funds from the central government through the Ministry of Village Affairs, BUMDes, which was formed in 2013, continues to develop the type of business as previously described.

\section{Variable of Collaborative Governance Regime}

Based on the model from Ansell and Gash (2007) the implementation model of collaborative governance there are 4 variables that can determine the success of collaborative governance as follows:

1) Starting Condition. The initial conditions before the collaboration management can be described as follows: The village government has considerable power to form villageowned enterprises (BUMDes). Thus the role of the Village Chief is very important in the process of establishing BUMDes. But the role is actually more as a facilitator to create a process that is able to build participation space for villagers. The process starts from the socialization to the formation of the BUMDes management. Furthermore, it is the authority of the BUMDes management to propose a business conception that will be built and developed. As a professional institution, BUMDes must be able to build an independent organizational system to run the entire process as a business institution. The role of the village head is to encourage the creation of BUMDes as an institution that is able to professionally manage all business processes and ensure that the process runs well. So it does not mean that the village head may determine everything that BUMDes must 
do. This is because BUMDes is a business institution that has very different considerations from government institutions in making a decision. The concept of BUMDes is different from other economic empowerment programs. BUMDes requires the participation of villagers throughout the birth process of BUMDes. BUMDes also requires that it be handled by the people chosen because of its capacity and not based on personal closeness with the village authorities or because they lost in the election of village head (Pilkades). Therefore, the selection of BUMDes officials cannot be indicated. Thus the position of power between BUMDes and private companies as partners does not have a power gap, even each party has a goal that leads to mutualism symbiosis.

2) Facilitative Leadership. As explained above, the role of the village head in managing BUMDES is more as facilitator rather than a supervisor for his subordinates. In the case of the Panggungharjo village head it turned out to have an advantage where the he is full of initiative and innovation. In fact, almost all informants agreed to strike the Village Head as a true innovator. Because creative ideas run by BUMDes are almost from the Village Head. Even one of the informants said that the making of the nyamplung oil was actually a personal project of the village head, but he did not want to enjoy it himself and preferred to submit a very profitable business idea to be managed by BUMDES and could be frofitable for all villagers.

3) Institutional design. All collaborations carried out between the Panggungharjo village government and the BUMDES Panggung Lestari and also the private sector have been based on official cooperation agreements. The duties, rights and obligations of each stakeholder have been formally regulated based on mutual agreement. Dialogue between stakeholders runs smoothly and effectively, because the objectives and benefits of each stakeholder are clear. The parties involved as stakeholders in the waste processing business are: a) Waste Management Institutions in the District and Bantul Regency, Village Waste Management Institutions, PKK Organizations as institutions that organize waste processing groups and the Community; b) R-UCO business stakeholders are Panggungharjo Village Government, BUMDES, community and collectors and PT. Danone Aqua; c) The Nyamplung oil business stakeholders are: Panggungharjo Village Government, BUMDES, PKK Organization which later established the Company namely PT. Sinergi Panggung Lestari (SPL), and PT. Mertani Group Innovation.

4) Collaborative process. Ansell and Gash (2007) describe this collaboration process to take place in a cycle, from face to face dialogue, trust building, commitment to process, shared understanding, intermediate outcomes which then need to be conducted again to evaluate the effectiveness of collaboration and determine whether collaboration will continue or not. What about the collaboration process that took place in the village of Panggungharjo? Dialogue between stakeholders has agreed to bond with one another with the objectives that are formulated transparently. With a process that is full of family, finally the village head managed to build the trust of other village officials and the BUMDES management to hold an MoU with the private parties that are relevant and competent in their business fields.

In the process of collaboration in the Panggungharjo village, the leadership role of the village head became central but did not dominate. Central means important because most of the ideas come from the Village Head who has broad and strategic insight. The second 
factor which is also important is the commitment and support of all BUMDES management and the high enthusiasm to work. The third factor is the support and participation of the people who want to carry out all directions from village officials and BUMDES officials to discipline and change their behavior, especially how to treat waste. This is also a service from the PKK organization that is effectively able to build communication and socialization with the people at lower levels.

With the same understanding between the village apparatus, the managers of BUMDES, PKK organizations and the community, the entire BUMDES program can run well and gain quite spectacular benefits so that the Panggungharjo village won the national championship title in the Village competition in 2014-2015. In 2017, it won the Property

\& Bank Award because it was considered to be outstanding and dedicated in carrying out development in the region through innovation (commitment to excellence and innovation). The Panggungharjo Village Government is considered successful in managing village funds optimally and is able to develop BUMDes well.

\section{Conclusion}

Collaborative governance held in Panggungharjo Village, Bantul Regency is one of the best practices that can be a source of inspiration and a model for other village development. Based on the results of this study there are at least several factors that are the key to its success which can theoretically be grouped into context and goal factors and driving factors. Then the two big factors will have implications for the collaborative process that is run.

Judging from the context and objective factors, all findings support effective collaborative governance that occurs in the village of Panggungharjo. As seen from the driving factor, the collaboration carried out is more of an internal driver rather than external driver which is then supported by high commitment from all existing village institutional elements. Therefore, both factors contribute to the collaboration process, starting from dialogue between stakeholders, trust building, commitment to process, shared understanding, and intermediate outcomes that show overall success of the process. This is evident from the achievements of the business productivity of BUMDES which are increasing year by year.

\section{Referensi:}

Afful-Koomson, T., dan Kwabena O. A. (2013). Collaborative Governance in Extractive Industries in Africa. Africa: Pixedit Limited

Agranoff, Robert, (2006), Inside Collaborative Networks: Ten Lessons for Public Managers, Public Administration Review Vol. 66, Special Issue: Collaborative Public Management (Dec., 2006), pp. 56-65

Ansell, Chris and Alison Gash (2008) Collaborative Governance in Theory and Practice, Journal of Public Administration Research and Theory, Volume 18, Issue 4, 1 October 2008, Pages 543-571, https://doi.org/10.1093/jopart/mum032 
Bardach, Eugene (1998), Getting Agencies to Work Together: The Theory and Practice of

Managerial Craftsmanship. 1998, Washington, DC: : Brookings Institution Press

Eakin, H., Eriksen, S., Eikeland, P.-O., \& Øyen, C. (2011). Public Sector Reform and Governance for Adaptation: Implications of New Public Management for Adaptive Capacity

in Mexico and Norway. Environmental Management, 47(3), 338-351.

http://doi.org/10.1007/s00267-010-9605-0

Emerson,Kirk; Tina Nabatchi; and Stephen Balogh (2012), An Integrative Framework for Collaborative Governance, Journal of Public Administration Research and Theory, Volume

22, Issue 1, 1 January 2012, Pages 1-29.

https://academic.oup.com/jpart/article/22/1/1/944908

Entwistle dan Martin (2005). From Competition To Collaboration In Public Service Delivery: A New Agenda For Research, Public Administration Vol. 83 No. 1, 2005 (233-242) (C) Blackwell Publishing Ltd., 9600 Garsington Road, Oxford OX4 2DQ, UK and 350 Main Street, Malden, MA 02148, USA.

Hufty, Marc (2011). "Investigating Policy Processes: The Governance Analytical Framework (GAF). In: Wiesmann, U., Hurni, H., et al. eds. Research for Sustainable Development:

Foundations, Experiences, and Perspectives". Bern: Geographica Bernensia: 403-24.

Huxham, Chris and Vangen, Siv (2005). Managing to collaborate: the theory and practice of collaborative advantage.Abingdon, UK: Routledge.

Kalimullah, Nazmul A., Kabir M. Ashraf A., MM. Ashaduzzaman Nour (2012). New Public Management: Emergence and Principles, BUP JOURNAL, Volume 1, Issue 1, September, ISSN: 2219-4851

Lincoln, Y., and E. Guba. (1985). Naturalistic Inquiry. Newbury Park, CA: Sage Publications.

O'Flynn, Janine L. and Wanna, John, Collaborative Governance: A New Era of Public Policy in Australia? (2011). Australia and New Zealand School of Government Series. Available at SSRN: https://ssrn.com/abstract=1927672

Stake, R. E. (2005). Qualitative Case Studies. In N. K. Denzin \& Y. S. Lincoln (Eds.), The Sage handbook of qualitative research (pp. 443-466). Thousand Oaks, CA, : Sage Publications Ltd.

VanWynsberghe, R., \& Khan, S. (2007). Redefining case study. International Journal of

Qualitative Methods, 6(2), Article 6. Retrieved [date] from http://www.ualberta.ca/ iiqm/backissues/6_2/vanwynsberghe.htm 